percentage of all respondents $(64 \%)$. Predictably, despite continuing evidence to the contrary ${ }^{45}$ advances in antemortem diagnostic techniques offsetting the need for necropsy were considered important by $54 \%$ of all respondents. Failure of junior doctors to ask for relatives' consent and an increased reluctance on their part to give consent were considered important by $53 \%$ and $52 \%$, respectively. Failure of pathologists to communicate their findings and increased aesthetic or emotional objections of clinicians to necropsy were considered important by only $18 \%$ and $16 \%$ of respondents, respectively.

We feel that the somewhat negative attitude to the necropsy expressed by junior clinical staff in our survey and the acknowledgement that medical education is lacking in this area are important, as it is frequently the most junior of doctors who are called on to ask a relative's consent for necropsy. We agree with the conclusions of Benbow that more care, effort, and sensitivity must be shown in the training of future doctors with regard to the necropsy.' Only then, perhaps, may the current unacceptable decline in the hospital necropsy rate be halted.

AP GILES
R DOSHI
GG MENON
MK KHAN
Departments of Histopathology and Neuropathology,
Brook General Hospital,
Shooters Hill, London SE18 4 LW

1 Benbow EW. Medical students' views on necropsies. J Clin Pathol 1990;43:969-76.

2 Cameron HM. Future of the hospital autopsy. Br J Hosp Med 1988;40:335.

3 Frederici HHR. Reflections on the postmortem audit. JAMA 1988;260:3461-5.

4 Goldman L, Sayon R, Robbins S, Conn LH, Bettmann $M$, Weisberg $M$. The value of the autopsy in three medical eras. $N$ Engl J Med 1983;308:1000-5.

5 Stevanovic G, Tucakovic G, Dotlic R, Kanjuh V. Correlation of clinical diagnoses with autopsy findings. Hum Pathol 1986;17: $1225-30$.

\section{Eponyms in pathology}

We are impressed by the series on eponyms in pathology. For extra finesse, another detail could be added, namely a note on the pronunciation of names.

An example of why this is necessary is given by the surname of the great Rudolf Ludwig Karl Virchow. Medical students and doctors have a variety of ways of pronouncing his name, often along the lines of verr-chow, to rhyme with per-plough, with the ch pronounced as in chew, or verr-koff, among several others.

Of 14 medical dictionaries and other works of reference in the Barnes Medical Library, University of Birmingham, all of which mention Virchow, only four gave a pronunciation: one said feer-show, one said verr-ko, one said fir-ko, and one, Webster's Medical Dictionary, ' said fir-cho, with the major stress on the first syllable, the $i$ as in hit, the $c h$ as in German ich or Scottish loch, and the $o$ as in go. According to RH Major, ${ }^{2}$ Virchow himself regarded the appropriate pronunciation as fir-cho.

It can be argued that there is no correct way to pronounce a name, but it is interesting, if nothing else, to find out how a person pronounced their own name. Your series could take the opportunity to educate pathologists with information that cannot always be worked out from first principles.

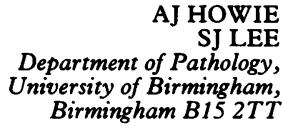

1 Virchow-Robin space. Webster's Medical Desk Dictionary. Springfield, Massachusetts: Merriam-Webster, 1986:759.

2 Major RH. Classic descriptions of disease with biographical sketches of the authors. Springfield, Illinois: Thomas, 1932:469-71

Dr Paola Domizio, who contributed the series on eponyms that is currently running in the Journal as space permits, comments:

I sympathise with Drs Howie and Lee that there is no guidance on how to pronounce eponymous terms. I wish it were possible. There are two difficulties. One is that usually when a person's name is given to a condition he or she is dead, and records may not survive of precisely how the name was pronounced. The other is that English freely assimilates foreign words and phrases and gives its own flavour to them. We do not speak of the Vulffian duct or the Artoose reaction, and we would probably not be able to do justice to shigellosis in the way that Shiga would have pronounced it.

To try to answer the specific question, our German senior house officer says Verchoff(the ch as in loch), Springer Verlag in London, who act for Virchow's Archiv in Berlin say Vershow (rhyme with cow), and the managing editor in London, Professor Colin Berry, says Verkow (again, rhyme with cow). I telephoned Berlin on the number given in the current international periodicals directory, and got a night-club.

Contributions to this and related series are welcomed. Please send your contributions to $\mathrm{Dr}$ Domizio at St Bartholomew's Hospital, London EC1A $7 B E$, or to the Editorial Office.

\section{BOOK REVIEWS}

All titles reviewed here are available from the BMJ Bookshop, PO Box 295, London WC1H 9TE. Prices include postage in the United Kingdom and for members of the British Forces Overseas, but overseas customers should add $£ 2$ per item for postage and packing. Payment can be made by cheque in sterling drawn on a United Kingdom bank, or by credit card (Mastercard, Visa or American Express) stating card number, expiratory date, and your full name.

Medicine and Management: Proceedings of the 9th Trent Region Seminar on Pathology. Ed J Pemberton. (Pp 64; soft cover, no price given). Trent RHA. 1990. ISBN 0951-1957-86.

The subjects dealt with at this seminar held by the Trent regional health authority included laboratories and management, molecular pathology, telepathology, the interface between research, teaching and diagnostic pathology, and laboratory accreditation. Pathologists and others with an interest in pathology, its development, management and involvement in patient management are advised to read this valuable seminar report. Pathologists will take heart that Dr Metters, deputy Chief Medical Officer, Department of Health, who discussed the future of pathology in England and Wales, is quoted as saying, "The trend for pathologists to take on a greater clinical workload should be encouraged. The risk, if it is not, will be the tendency to see the laboratory simply as a factory, to produce test results. That would be very retrograde"

In an important final paragraph Dr Metters reasons as follows: "To conclude on a note of optimism: although at present the consequences of the White Paper for pathology may not be clear, speculation about the future is not necessary as pathology has a fundamental part to play in the diagnostic services of the NHS. If the diagnostic service is not right, the therapy won't be either. So whatever happens as a result of the White Paper fundamental importance must be attached to maintaining the quality of the pathology service and its vital contribution to diagnosis and treatment. Whilst pressures on staffing and cost efficiency may be on the increase, it remains essential that pathology services continue to provide an effective, on the spot, 24 hour service for all NHS hospitals, whether they are directly managed by Health Authorities or run by self governing trusts". Pathologists will wholeheartedly agree with Dr Metters' sentiments.

C ROBERTS

Manual of Laboratory Immunology. 2nd ed. LE Miller, HR Ludke, JE Peacock, RH Tomar. (Pp 427; £25.56.) Lea \& Febiger. 1991. ISBN 0-8121-1319-5

This is the second edition of what, the authors claim, is a procedural manual of humoral and cellular immunology intended for a range of laboratory professionals. It starts with a commendably short and concise introduction to immunology with two sound chapters on specimen handling and the principles of serological methods.

The chapter on lymphocyte assessment occurs early, but it is not particularly easy to follow, nor can one easily discern the practical procedures required. It does not start by discussing the sample collection and handling (non-refrigeration, time from venesection to testing, etc.). It gives the uses of the techniques and discusses the principles, and at the end provides the practical instructions.

The section on immunoglobulins is disappointing and does not discuss the relative merits of radial diffusion and other automated fluid phase techniques widely used today. The characterisation of paraproteins is covered by immunoelectrophoresis and immunofixation, but there is no discussion of Bence Jones protein detection or paraprotein quantitation and its problems. Likewise, the section on complement is disappointing. While it goes into some detail of the complement pathways and the various complement deficiencies, it does not indicate the problems of quantitation of individual components, which ones 